International Journal of Health Sciences
Available online at www.sciencescholar.us
Vol. 5 No. 3, December 2021, pages: 630-638
e-ISSN: 2550-696X, p-ISSN: 2550-6978
https://doi.org/10.53730/ijhs.v5n3.2720

\title{
Public Administration Strategy of Healthcare System for Seniors
}

\author{
(1) corssarark \\ Nina Grigorievna Shamshurina a, Victor Ivanovich Shamshurin b, Yuliya Aleksandrovna Laamarti c, \\ Lyubov Nikolaevna Ryabchikova d, Alexander Alexandrovich Nikolaev e, \\ Pavel Aleksandrovich Peremibeda ${ }^{\mathrm{f}}$
}

Manuscript submitted: 23 July 2021, Manuscript revised: 18 October 2021, Accepted for publication: 25 November 2021

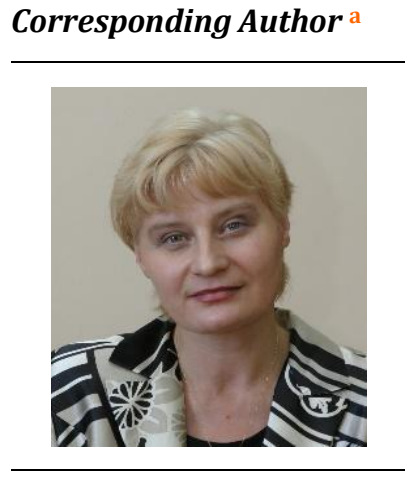

Keywords

geriatrics;

gerontology;

healthcare authority;

healthcare organization;

healthcare system;

public health

preservation;

senior health;

\begin{abstract}
The goal of the study is to restructure society's attitude toward the needs of the elderly. The article addresses the methodology of state social policy and possible innovations in funding and economic methods for public administration in the healthcare system for seniors. The novelty of the work is ensured by the concept of managed older age and a start-up proposal to create the State Direct Investment Fund "Senior Generation" functioning as an entity responsible for the development of the organizational foundations for gerontology and geriatrics services. The practical significance of the study lies in the optimization of the modern management model of care for the older generation and a philosophical study of age as a potential in management in both individual and societal regards. This strategy can serve as a basis for public administration of the healthcare system for the elderly accounting for the diversity of seniors as a social stratum.
\end{abstract}

International Journal of Health Sciences (C) 2021. This is an open access article under the CC BY-NC-ND license (https://creativecommons.org/licenses/by-nc-nd/4.0/).

\section{Contents}

Abstract

1 Introduction.

2 Materials and Methods

3 Results and Discussions

a First Moscow State Medical University (Sechenov University), Moscow, Russia

b Lomonosov Moscow State University, Moscow, Russia

c Financial University under the Government of the Russian Federation, Moscow, Russia

d Financial University under the Government of the Russian Federation, Moscow, Russia

e Financial University under the Government of the Russian Federation, Moscow, Russia

f Financial University under the Government of the Russian Federation, Moscow, Russia 


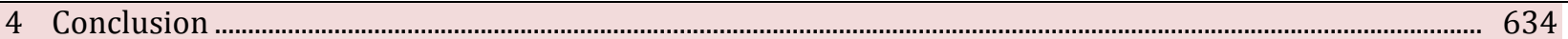

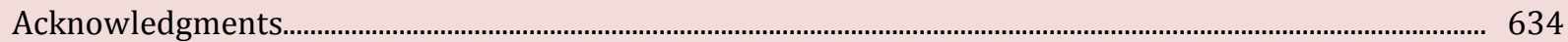

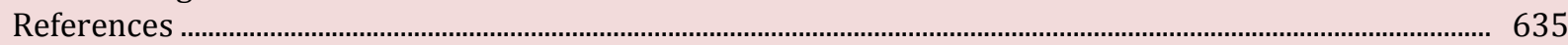

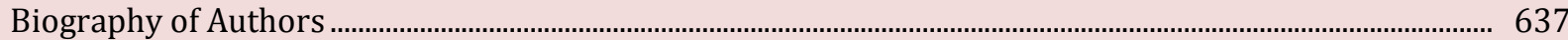

\section{Introduction}

Consideration of the problem of old age requires the utmost discretion and tact, a more appropriate strategy would be to abandon this term altogether and instead speak of various degrees of people's age maturity and health (Pronk et al., 2004). Illnesses are a universal human problem, which must be considered in the regulation of labor relations, in which it is more important than the employee meets certain qualifications, while age may not play a major role (Giddens, 2018; Pashina, 2021). However, a thoughtful attitude toward senior people certainly involves treating them as complete and equal individuals, as well as the active respect for age on the part of society (Backhous, 2006; Glukhov \& Stakhovskaia, 2021; Grainger, 2004). Society should not view the older generation as obsolete, but, on the contrary, should help them to maintain a full life in all its diversity (Alexander, 1995; Grober, 2017; Roik, 2020).

In this context, medicine and healthcare can be viewed as an economic specification of the state social policy in the field of public health preservation, including that of the older generation (Putin, 2012). The example of the well-being of older people achieved by society vividly demonstrates the importance of a strategic perspective on the state social policy, which gives way to all kinds of practices (Yu \& Kolosnitsyna, 2015). It is also important to clearly distinguish between and regulate the rights and supporting responsibilities of both the elderly citizens themselves and the state and municipal authorities responsible for the quality of the lives of at least four groups of seniors (Makoni, 2017; Makoni \& Grainger, 2002; Cohen et al., 2017; Barrutia \& Echebarria, 2013).

The first group is the citizens of retirement age who can work, as well as the willingness and physical and spiritual strength matching the necessary qualifications, to continue to work. The second group includes retirement age citizens with working ability who, for instance, have the necessary physical capacity but are not willing to continue to work for some personal, family, or worldview reasons. The third group is the retirement age citizens who cannot work but consider themselves capable of continuing their employment relationship (Tolson et al., 2011; Fabbri et al., 2015). The fourth group is citizens without working ability who lack both physical and moral capacity and desire to continue working. The latter is the "easiest" case, which is already accounted for by the existing rules and regulations. The aforementioned groups require not only recognition but also the most precise legislative elaboration of the methods of public administration aimed at creating optimal living conditions for each of the four strata of the older generation (Rudakova, 2014; Walker, 2007).

\section{Literature review}

As stated by Ilin (1993), the state is established by people and for the people, therefore, it must perform its constitutional functions of ensuring the rights, freedoms, and obligations of citizens in the social sphere, developing social policy priorities, and organizing their practical implementation. At the beginning of the 20th century, Sombart (1900), in his Ideals of Social Policy addressed the question of the essence of social policy within the framework of state activity and considered the most important thing to be state support, above all, for its citizens. S.I. Hessen (1887-1950) believed that the main task of the state is creating the social conditions necessary for personal self-development and eliminating the obstacles that arise along this way.

However, it is unwise to place too many expectations on the state. Chicherin (2005), argues that "The state is not able to do everything, but it can do much by promoting the free movement of forces on which the welfare of human societies ultimately depends and by resolving the questions arising in this field" (p. 245). The goal of the present study is to develop a concept for age management and, based on this concept, to create a system of specific economic measures to improve the quality of life of the older generation carried out through the methods of public administration (Arundel, 2017; Braams et al.,2021; Widana et al., 2021).

Shamshurina, N. G., Shamshurin, V. I., Laamarti, Y. A., Ryabchikova, L. N., Nikolaev, A. A., \& Peremibeda, P. A. (2021). Public administration strategy of healthcare system for seniors. International Journal of Health Sciences, 


\section{Materials and Methods}

The study goals are pursued through the method of interdisciplinary analysis and the study of applied research on the problem, as well as strategies, laws, state programs, indicators of state statistics, the conceptions offered by institutes and centers of gerontology and geriatrics, the results of sociological studies, and other materials on the development of socio-economic relations in the field of healthcare and social security of the older generation of citizens (Caceres, 2019). An analysis of the methods of state and municipal administration focused on the organization of older people's lives in Russian and foreign practice is also conducted.

\section{Results and Discussions}

In the Russian Federation, the structure of the project part of the State Program "Development of Healthcare" currently includes two federal projects implemented as part of the national project "Demography": "Strengthening Public Health" and "Older Generation". The goal of all Russian national projects, particularly the ones associated with the quality of life of the older generation, is to not only preserve but improve the quality of life, therefore, it is necessary to consider the fact that, as previously mentioned, the group of senior citizens includes four categories of people with drastically different motivations. A landmark in this regard was the first meeting "On the progress of the federal project 'Older Generation' of the national project 'Demography'. Meeting on the projects 'Demography' and 'Older Generation'”, at which it was rightly stated that in solving the problems of the project, all action cannot be centralized and passed on to the federal level, it mostly concerns the level of the regions. On the other hand, the bar set by the implementation of the project "Older Generation" cannot be lowered, since "that would be the worst result of common work - of both the state, the regions, the non-profit organizations, generally all those invested in this topic" (Medvedev, 2019).

In our view, to achieve real results in the "Older Generation" project, at the initial stage, it is necessary to create a self-sufficient institution of financing in the form of the State Direct Investment Fund "Senior Generation" replenished from federal, regional, municipal, commercial, and non-commercial sources and to determine the shares of participation in it accounting for the specific needs of the contingent in the regions. Responsibility for the receipt and expenditure of funds should be under the control of clearly identified, wellknown, and effective managers engaged in these activities regularly. Whereas before we considered the age management concept from the point of personal self-organization and self-development, herein we are addressing the creation of infrastructural prerequisites of the organizational and institutional nature. For example, the proposed State Direct Investment Fund "Senior Generation" can consist of the following components: 1) financing from the federal budget $-60 \%$; from the budget of the constituent entity of the Russian Federation and other sources - 40\%; 2) performing three main functions: direct financing of nursing departments of state, budgetary, and autonomous healthcare institutions; control over the activities of private healthcare organizations caring for the elderly, including control over the organizations established in the form of public-private partnerships; the functions of a methodological center for the development of gerontological services in the Russian Federation. There has long been a need in society for nursing departments, and medical schools are training nursing administrators. For this idea to finally be put into practice, what becomes vital at the initial stage is direct financing from the State Direct Investment Fund "Senior Generation" for nursing departments in hospitals as an additional source of funding for healthcare organizations and day hospitals with geriatric services. It is also advisable to provide tax incentives in the form of a $0 \%$ profit tax rate, as has already been done by the Russian government for paid medical services (Government of the Russian Federation, 2011). For nursing departments, it is inappropriate to separate paid medical services and paid services in the preferential taxation, since the modern model of care for the elderly is at the intersection of social services and medical care. A major role could be played by the involvement of religious organizations in medical institutions and social services and support for the activities of the Sisters of Mercy.

The feature of modern healthcare is that services of therapeutic and preventive nature provided to the elderly may be costly and economically unprofitable in the short term, yet in terms of the country's development strategy, the medical and social effects make their organization essential (Kalache \& Kickbush, 
1997; Susilo et al., 2021). When calculating social performance indicators, it must be considered that, on average, older people are 2.5 times more likely to go to the doctor, 2 times more likely to be hospitalized, and stay in hospitals 1.5 times longer. Thus, financial expenses for the treatment of an elderly person are 2 to 3 times higher than those for the provision of medical care to persons of young and middle age (Mishbahuddin et al., 2021). This must be taken into consideration in the financing of federal and regional programs.

What is proposed as the basis of the organization of comprehensive assistance for the elderly is the following organizational scheme: the creation of geriatric care offices in every district polyclinic or daycare center; organization of nursing departments for the treatment of the elderly in the structure of every multidisciplinary hospital, both at the expense of regional budgets and on a fee basis. Professional training of medical and nursing staff in geriatrics as part of continuing medical education; development of a network of small nursing homes in the private healthcare sector, including rehabilitation homes, for convalescence and long-term care of elderly patients (Fulmer, 2020). The latter is important for increasing the efficiency of the use of expensive hospital beds in specialized clinical departments. Expansion of the network of medical-social institutions, both publicly and privately owned, for the permanent stay of elderly and senile persons living alone (Carchi et al., 2021).

The quantitative characterization of the quality of state and municipal public administration of the processes of improving the lives of the older generation, in our opinion, can be reflected by such indicators as the budgetary growth rate of federal and especially regional budgets allocated for the federal project "Older Generation" from consolidated budget revenues, which will testify to the authorities' ability to plan regional (settlement) budget expenditures for the needs of the older generation, and to the development of the social partnership. For the sphere of healthcare, we propose the indicator of the efficiency of program-targeted budget expenditures planning of a healthcare administration body $C P R$ as the ratio between the execution of expenditures on activities under targeted healthcare programs for the period (Ctpr) and the execution of expenses for the same period (Ct), or: $\mathrm{cpr}=\mathrm{Ctpr} / \mathrm{Ct} \times 100, \%$. As a result, the indicator determines the share of expenditures of a healthcare executive body on the federal program "Senior Generation" in the total expenditures for the period. Through sociological surveys, it is important to determine and calculate the proportion of older people who are satisfied with their situation (Qsat.) in the total number of senior citizens in the region (Q) based on the indicator ksat., specifically: ksat.= Qsat./ Q x 100, \%. To monitor the work of healthcare organizations, municipal and regional healthcare authorities can use such indicators of the effectiveness of the organization's medical staff as the completeness and timeliness of health assessments among the elderly, the vaccination and immunization of this group of patients, the completeness of their clinical examination in preparation for hospitalization, coverage with fluorographic examinations, the provision of services by doctors in remote areas, especially in rural areas, prevention and reduction of neglected cases of severe diseases and death of elderly patients not observed by a doctor, and some other performance indicators.

The application of the above-mentioned indicators in the practice of public administration bodies will provide information about the growth of social efficiency of the expenditure of administrative structures' financial resources. Regular monitoring and surveys, aside from giving evidence of the growth of social efficiency of financial resource spending in the region, allow receiving feedback based on senior citizens' selfassessment of their health and observing the results of activities of subordinate medical institutions (Kocken \& Voorham, 1998).

Following the model of an effective state, "the quality of public administration presupposes compliance with the requirements of the reasonableness of state intervention" (Yuzhakov et al., 2020). We concur with this provision and emphasize that public administration is the most effective when carried out through economic methods, the basis for the use of which is created by federal and regional legislation. In exchange for tax incentives (which can be enshrined in the regional legislation), and to supplement the financial sources of the regional healthcare and social budget, what could serve as an indicator of social effectiveness of authorities in the constituent entities of the Russian Federation is a predetermined value of additional financial allocations from business entities for the development of the social sphere of the city or region. The effectiveness could be determined by the dynamics of growth of this indicator. State authorities, encouraging "programs of socially responsible business", including those in the form of public-private interaction and partnership, create conditions for a fairer distribution of resources (Ugriumov, 2014; Novoa, 2021).

Shamshurina, N. G., Shamshurin, V. I., Laamarti, Y. A., Ryabchikova, L. N., Nikolaev, A. A., \& Peremibeda, P. A. (2021). Public administration strategy of healthcare system for seniors. International Journal of Health Sciences, 
The criteria of the quality of administrative activity of state authorities of any level are good demographic indicators and a high level of healthcare development (Dobroliubova, 2020; Soloveva, 2016). The point in the coordinate system of social policy is the correspondence of the subsistence minimum including not only the "food basket", but also cultural needs, leisure, education, medicine, transport, and housing costs, to the minimum wage commensurate with these costs, social benefits or pensions, other types of social security, certain types of social support as a source of income (Li-he \& Qi, 2019). Only then can we focus on caring for a specific person, including those who are of age.

What is more cost-effective is implementing social programs to engage the able and willing group of senior citizens in active labor activity in the context of the increasing aging of society as a whole and the decreasing number of employable citizens to the unemployable, since in this case, this group of citizens provides for itself. The "Strategy of Actions in the Interests of Senior Citizens in the Russian Federation until 2025" describes the social policy of ensuring the replacement of up to $40 \%$ of lost earning by the old-age labor pension with a standard insurance period and average salary and, as a result, achieving an acceptable level of pension for the middle class through participation in corporate and private pension systems. However, there has been no clarification about the mechanism for reaching this goal and "a decent and acceptable level of pension" for the middle class. Nevertheless, without drastic measures concerning pension policy and the correspondence of salaries that determine pension amount to the immediate needs, there will be no dramatic changes in the same demographics.

\section{Conclusion}

Among the emerging innovations in the funding and public administration of the healthcare system for older citizens are the creation of a network of gerontology centers, a system of long-term care for the elderly at the intersection of social services and medical care, and the use of hospital-substituting technologies. At the modern stage, public administration must certainly mostly rely on economic methods of regulation. The startup of the State Direct Investment Fund "Senior Generation" as a single entity responsible for finances from various sources would be a driving force in solving the problems of senior citizens. This Fund is intended to perform three main functions: 1) direct financing of nursing departments, daycare hospitals with geriatric services, and state and municipal healthcare systems; 2) control over the activities of private healthcare organizations and public-private partnerships that provide care to the elderly; 3 ) a methodological center for the development of gerontological services in the Russian Federation.

We believe that a measure necessary for the fourth stratum of the elderly is the creation of the Federal Register of Mercy "Senior Generation" for the development of targeted medical care and the identification of the amount of its target funding. Direct funding of nursing departments from the proposed State Direct Investment Fund "Senior Generation" is an additional source of funding for 24-hour and daycare hospitals following the state assignment. Healthcare institutions that proactively organize such departments providing medical care combined with geriatric care services on a fee-for-service basis should initially be exempt from paying tax on profits received not only from medical but also additional services to allow them to reinvest the income received in the development of gerontological and geriatric services. To determine the public effectiveness of public administration of the healthcare system for the older generation and the social sphere of the economy, it is necessary to approve a system of indicators of qualitative changes in the life of the older citizens in the Russian Federation, as well as to define and use the index of active longevity in economic statistics to analyze the development of gerontological care as an important element of all social and medical care in the conditions of aging of the world population.

\section{Acknowledgments}

We are grateful to two anonymous reviewers for their valuable comments on the earlier version of this paper. 


\section{References}

Alexander, J. (1995). Modern, ante, post, and neo: how intellectuals have coded, narreted, and explained the" crisis of our times. Alexander, J. Fin-desiècle social theory: relativism, reduction, and the problem of reason. Londres: Verso, 7-64.

Arundel, A. (2017). Rethinking the effect of risk aversion on the benefits of service innovations in public administration agencies. Research Policy, 46(5), 900-910. https://doi.org/10.1016/j.respol.2017.03.009

Backhaus, P. (2006). Care, control, and communication: Linguistic interaction between staff and residents in a Japanese nursing home for the elderly.

Barrutia, J. M., \& Echebarria, C. (2013). Why do municipal authorities participate in-and are loyal to-LA21 networks?. Journal of Cleaner Production, 41, 42-52. https://doi.org/10.1016/j.jclepro.2012.10.006

Braams, R. B., Wesseling, J. H., Meijer, A. J., \& Hekkert, M. P. (2021). Legitimizing transformative government: Aligning essential government tasks from transition literature with normative arguments about legitimacy from Public Administration traditions. Environmental Innovation and Societal Transitions, 39, 191-205. https://doi.org/10.1016/j.eist.2021.04.004

Caceres, B. A. (2019). Care of LGBTQ older adults: what geriatric nurses must know. Geriatric Nursing, 40(3), 342-343. https://doi.org/10.1016/j.gerinurse.2019.05.006

Carchi, J. A. Y. ., Catagua, T. C. M. ., Rivera, D. G. B. ., Mera, V. B. ., \& Rosario, M. del . (2021). From beginner to expert, experience of the rotating nursing intern in pre-professional practice. International Journal of Health Sciences, 5(2), 111-117. https://doi.org/10.29332/ijhs.v5n2.1291

Chicherin, B. N. (2005). Sobstvennost'i gosudarstvo [Property and the state], 2 vols. St. Petersburg: Publishing house of the Russian Christian Humanitarian Academy.

Cohen, O., Goldberg, A., Lahad, M., \& Aharonson-Daniel, L. (2017). Building resilience: The relationship between information provided by municipal authorities during emergency situations and community resilience. Technological Forecasting and Social Change, 121, 119-125. https://doi.org/10.1016/j.techfore.2016.11.008

Dobroliubova, E. I. (2020). K voprosu o vzaimosviazi kachestva gosudarstvennogo upravleniia i chelovecheskogo razvitiia [On the relationship between the quality of public administration and human development]. Public administration issues, 4, 31-38.

Fabbri, E., Zoli, M., Gonzalez-Freire, M., Salive, M. E., Studenski, S. A., \& Ferrucci, L. (2015). Aging and multimorbidity: new tasks, priorities, and frontiers for integrated gerontological and clinical research.Journal of the American Medical Directors Association, 16(8), 640-647. https://doi.org/10.1016/j.jamda.2015.03.013

Fulmer, T. (2020). A retrospective/prospective on the future of geriatric nursing. Geriatric Nursing, 41(1), 2931. https://doi.org/10.1016/j.gerinurse.2020.01.012

Giddens, A. (2018). Osnovnye poniatiia v sotsiologii [Basic concepts in sociology]. Moscow, Russia: HSE Publishing House.

Glukhov, A. P., \& Stakhovskaia, Iu. M. (2021). Tsifrovoi razryv v fokuse mezhpokolencheskoi kommunikatsii [The digital divide as the focus of intergenerational communication]. Vestnik Tomskogo gosudarstvennogo universiteta. Filosofiia. Sotsiologiia. Politologiia, 59, 148-155.

Government of the Russian Federation. (2011). Decree of the Government of the Russian Federation of November 10, 2011 No. 917 (as amended on March 6, 2015) "On the approval of the list of types of educational and medical activities carried out by organizations to apply the tax rate of 0 percent for corporate income tax".

Grainger, K. (2004). Communication and the institutionalized elderly. In Handbook of communication and aging research (pp. 499-518). Routledge.

Grober, E. M. (2017). Kriterialnyye kharakteristiki sotsiokul'turnoy politiki Rossiiskoi Federatsii [Criteriabased characteristics of the socio-cultural policy of the Russian Federation]. Sovremennye nauchnye issledovaniia i innovatsii, 7(75), 27.

Ilin, I. A. (1993). Philosophy of law. Moral philosophy. Works: in, 2.

Kalache, A., \& Kickbusch, I. (1997). A global strategy for healthy ageing. World health, 50(4), 4-5.

Kocken, P. L., \& Voorham, A. J. J. (1998). Effects of a peer-led senior health education program. Patient Education and Counseling, 34(1), 15-23. https://doi.org/10.1016/S0738-3991(98)00042-1

Shamshurina, N. G., Shamshurin, V. I., Laamarti, Y. A., Ryabchikova, L. N., Nikolaev, A. A., \& Peremibeda, P. A. (2021). Public administration strategy of healthcare system for seniors. International Journal of Health Sciences, 
Li-he, H. U. A. N. G., \& Qi, Z. H. U. (2019). Pragmatic Studies in Geronto-linguistics: Perspectives, Methods and Topics. Journal of East China Normal University (Philosophy and Social Sciences), 51(6), 129.

Makoni, S. (2017). From elderspeak to gerontolinguistics: Sociolinguistic myths. The Oxford handbook of language and society, 350-369.

Makoni, S., \& Grainger, K. (2002). Comparative gerontologistics. Journal Social Studies, 58(4), 805-824.

Medvedev, D. A. (2019). On the progress of the federal project "Older Generation" of the national project "Demography". Meeting on the projects 'Demography' and 'Older Generation'. Rostov-on-Don.

Mishbahuddin, M., Amirah, A., Fadli, F., Justicia, A. K., \& Ernawati, K. (2021). Understanding Islamic commandments to maintain people's health and environment: a critical review on literature. International Journal of Health Sciences, 5(2), 202-211. https://doi.org/10.29332/ijhs.v5n2.1427

Novoa, R. B. (2021). State of the art and future applications of digital health in Chile. International Journal of Health \& Medical Sciences, 4(3), 355-361.

Pashina, L. A. (2021). Konstituirovanie gerontologicheskoi paradigmy znaniia i ee sovremennye perspektivy [Constitution of the gerontological paradigm of knowledge and its modern perspectives]. Vestnik Tomskogo gosudarstvennogo universiteta. Filosofiia. Sotsiologiia. Politologiia, 59, 101-111.

Pronk, N. P., Anderson, L. H., Crain, A. L., Martinson, B. C., O'Connor, P. J., Sherwood, N. E., \& Whitebird, R. R. (2004). Meeting recommendations for multiple healthy lifestyle factors: prevalence, clustering, and predictors among adolescent, adult, and senior health plan members. American journal of preventive medicine, 27(2), 25-33. https://doi.org/10.1016/j.amepre.2004.04.022

Putin, V. V. (2012). Stroitelstvo spravedlivosti. Sotsialnaia politika dlia Rossii [Building justice. Social policy for Russia]. Komsomolskaia pravda.

Roik, V. D. (2020). Sotsialnaia politika gosudarstva: sotsialnaia splochennost [Social policy of the state: social cohesion]. Moscow, Russia: Iurait.

Rudakova, O. S. (2014). Upravlenie realizatsiei sotsialnykh programm v rossiiskom obshchestve na primere regionalnoi programmy "Starshee pokolenie" [Managing the implementation of social programs in Russian society on the example of the regional program "Older Generation"]. Gumanitarnye nauchnye issledovaniia. 1(29), 24.

Solov'eva, M. F. (2016). O realizatsii sotsial'noi politiki v Rossii [On the implementation of social policy in Russia]. Kontsept= Concept, (T4), 26-30.

Sombart, W. (1900). Idealy sotsialnoi politiki [Ideals of Social Policy]. Saint Petersburg, Russian empire: Znanie.

Susilo, C. B., Jayanto, I., \& Kusumawaty, I. (2021). Understanding digital technology trends in healthcare and preventive strategy. International Journal of Health \& Medical Sciences, 4(3), 347-354.

Tolson, D., Rolland, Y., Andrieu, S., Aquino, J. P., Beard, J., Benetos, A., ... \& of Gerontology, T. I. A. (2011). International Association of Gerontology and Geriatrics: A global agenda for clinical research and quality of care in nursing homes. Journal of the American Medical Directors Association, 12(3), 184-189. https://doi.org/10.1016/j.jamda.2010.12.013

Ugriumov, E. S. (2014). Printsip spravedlivosti nalogooblozheniia kak osnova provedeniia sotsialnoi politiki gosudarstva [The principle of tax fairness as the basis for the implementation of the state social policy]. Politika, gosudarstvo i pravo, 1(25), 2.

Walker, A. (2007). Why involve older people in research?. Age and Ageing, 36(5), 481-483.

Widana, I.K., Sumetri, N.W., Sutapa, I.K., Suryasa, W. (2021). Anthropometric measures for better cardiovascular and musculoskeletal health. Computer Applications in Engineering Education, 29(3), 550561. https://doi.org/10.1002/cae.22202

Yu, S., \& Kolosnitsyna, M. (2015). Pensionery na rossiyskom rynke truda: tendentsii ekonomicheskoy aktivnosti lyudey pensionnogo vozrasta [Pensioners on the Russian labour market: trends of economic activity in pension age]. Demograficheskoe obozrenie, 2, 36-53.

Yuzhakov, V. N., Talapina, E. V., Dobrolyubova, E. I., \& Tikhomirov, Y. A. (2020). Initsia-tivnyi proekt zakona ob obespechenii kachestva gosudarstvennogo upravleniya [Initiative Draft Law on Public Administration Quality Assurance]. Moscow:«Delo» RANKhiGS. 


\section{Biography of Authors}

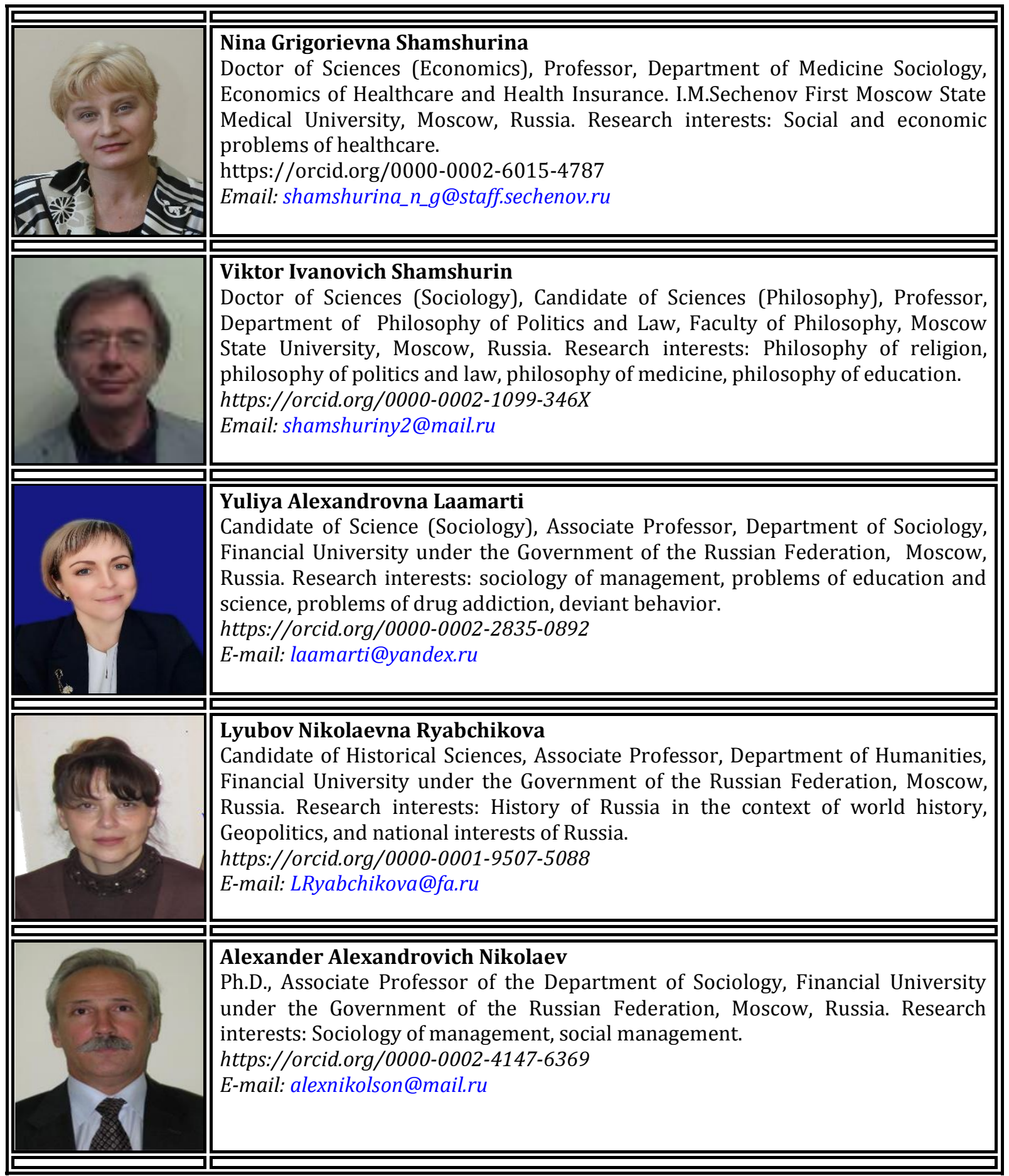

Shamshurina, N. G., Shamshurin, V. I., Laamarti, Y. A., Ryabchikova, L. N., Nikolaev, A. A., \& Peremibeda, P. A. (2021). Public administration strategy of healthcare system for seniors. International Journal of Health Sciences, 5(3), 630-638. https://doi.org/10.53730/ijhs.v5n3.2720 


\begin{tabular}{|l|l|}
\hline & $\begin{array}{l}\text { Pavel Aleksandrovich Peremibeda } \\
\text { Candidate of sociological sciences, Associate Professor, Department of sociology, } \\
\text { Financial University under the Government of the Russian Federation, Moscow, } \\
\text { Russia. Research interests: Social institutions of power and strategic management, } \\
\text { Solidarization and integration of social communities, Dialectics of the } \\
\text { development of complex social systems, Sociology of childhood. Sociology of Art, } \\
\text { Social artifacts of capitalism and socialism. } \\
\text { https://orcid.org/0000-0002-2224-1505 } \\
\text { E-mail: pperemibeda@mail.ru }\end{array}$ \\
\hline
\end{tabular}

